\title{
An in silico Analysis of Upstream Regulatory Modules (URMs) of Tapetum Specific Genes to Identify Regulatory cis-Elements and Transcription Factors
}

\author{
Preeti Apurve Sharma, Pradeep Kumar Burma* \\ Department of Genetics, University of Delhi South Campus, New Delhi, India \\ Email: *pburma@south.du.ac.in
}

How to cite this paper: Sharma, P.A. and Burma, P.K. (2018) An in silico Analysis of Upstream Regulatory Modules (URMs) of Tapetum Specific Genes to Identify Regulatory cis-Elements and Transcription Factors. American Journal of Molecular Biology, 8, 13-25.

https://doi.org/10.4236/ajmb.2018.81002

Received: October 10, 2017

Accepted: December 15, 2017

Published: December 18, 2017

Copyright $\odot 2018$ by authors and Scientific Research Publishing Inc. This work is licensed under the Creative Commons Attribution International License (CC BY 4.0).

http://creativecommons.org/licenses/by/4.0/

\begin{abstract}
The present work presents an in silico analysis of Upstream Regulatory Modules (URMs) of genes expressed in tapetum specific manner in dicotyledon and monocotyledon plants. In the current analysis, we identified several motifs conserved in these URMs of which ten were observed to be part of known cis-elements using tools and databases like MEME, PLACE, MAST and TFSEARCH. We also identified that binding sites for two transcription factors, DOF and WRKY71 were found to be present in majority of the URMs.
\end{abstract}

\section{Keywords}

Tapetum Specific Promoter, cis-Elements, Transcription Factors

\section{Introduction}

Tapetum is the innermost layer of the anther wall of plants. It performs the function of a nourishing tissue that remains in continuity with the pollen mother cell through plasmadesmatal connections till the formation of meiocytes occurs in young anther. Tapetum varies from unilayer to multilayer in different plant species and can be uninucleate or multinucleate. Although tapetum cells form a single or at-most a few cell layers in the anther tissue, several studies have been carried out to understand how these cell layers develop and the functions played by them in pollen cell development [1] [2] [3] [4]. These studies have led to the identification of several genes expressed in tapetum specific manner. Such genes have mainly been identified by analyzing comparative cDNA libraries, subtractive hybridization, microarray analysis, in-situ hybridization and in recent years 
by Laser Dissection Microscopy followed by RNA sequencing [1] [5]-[16].

TA29 from Nicotiana tabacum [1] and A9 from Arabidopsis thaliana [6] are examples of tapetum specific genes that were identified in early years. The promoters of these genes known as TA29 and A9 promoters have been used extensively in the expression of transgenes like barnase and barstar from Bacillus amyloliquifaciens to develop pollination control systems for hybrid seed production [5] [17] [18] [19] [20] [21]. Tight regulation of these promoters leading to tapetum specific expression was the key to success of this system. Attaining a robust tissue specificity of a promoter may need the combinatorial interplay of positive and negative regulators (transcription factors, TFs). The TFs would bring about their outcome by binding to the promoter through specific motifs or cis-elements. Several tapetum specific promoters have been identified till date, examples of which have been summarized in Table 1. However, there is limited knowledge about the transcription factors or the cis-elements of the promoters that are important for regulating these promoters. Although some tapetum specific promoters have been recently characterized in details e.g. OsLTP6 from rice [22] and A9 from Arabidopsis [23] in most of the studies, the characterization is limited to identifying the minimum length of the promoter needed for tapetum specific expression.

The present work is an attempt to identify conserved motifs/cis-elements present in genes expressing in the tapetum tissue of dicotyledon and monocotyledon plants. Further, putative TFs that may bind to these elements have also been predicted. Information generated from this work can be used for experimental validation.

\section{Method}

Motif Based Sequence Analysis Suite, MEME suite ver. 4.9.1 [24] was used to find out the conserved motifs in the different datasets. PLACE database [25] was used to figure out the cis-elements from the conserved motifs so obtained. Multiple Alignment \& Search Tool, MAST ver. 4.9.1 [26] was used to attain consensus sequence of the conserved motifs obtained from MEME analysis. TFSEARCH software ver.1.3 [27] was used to find the putative TFBS and the transcription factors.

\section{Results and Discussion}

A literature survey was carried out to identify genes that expressed in a tapetum or anther specific manner. A total of 34 genes, 24 from dicot and 10 from monocot plants were identified and used in the present analysis (Table 1). From these, two datasets were developed comprising of $600 \mathrm{bp}$ Upstream Regulatory Module (URM), one from dicot and another from monocot species. URMs [40] are defined as a region of a gene upstream to the translational start site, which includes the 5'UTR. Analyzing the URM was necessary in this analysis as in most cases the transcriptional start site has not been experimentally identified. 
Table 1. Details of the URMs of the genes from both dicot and monocot plants used in the present analysis.

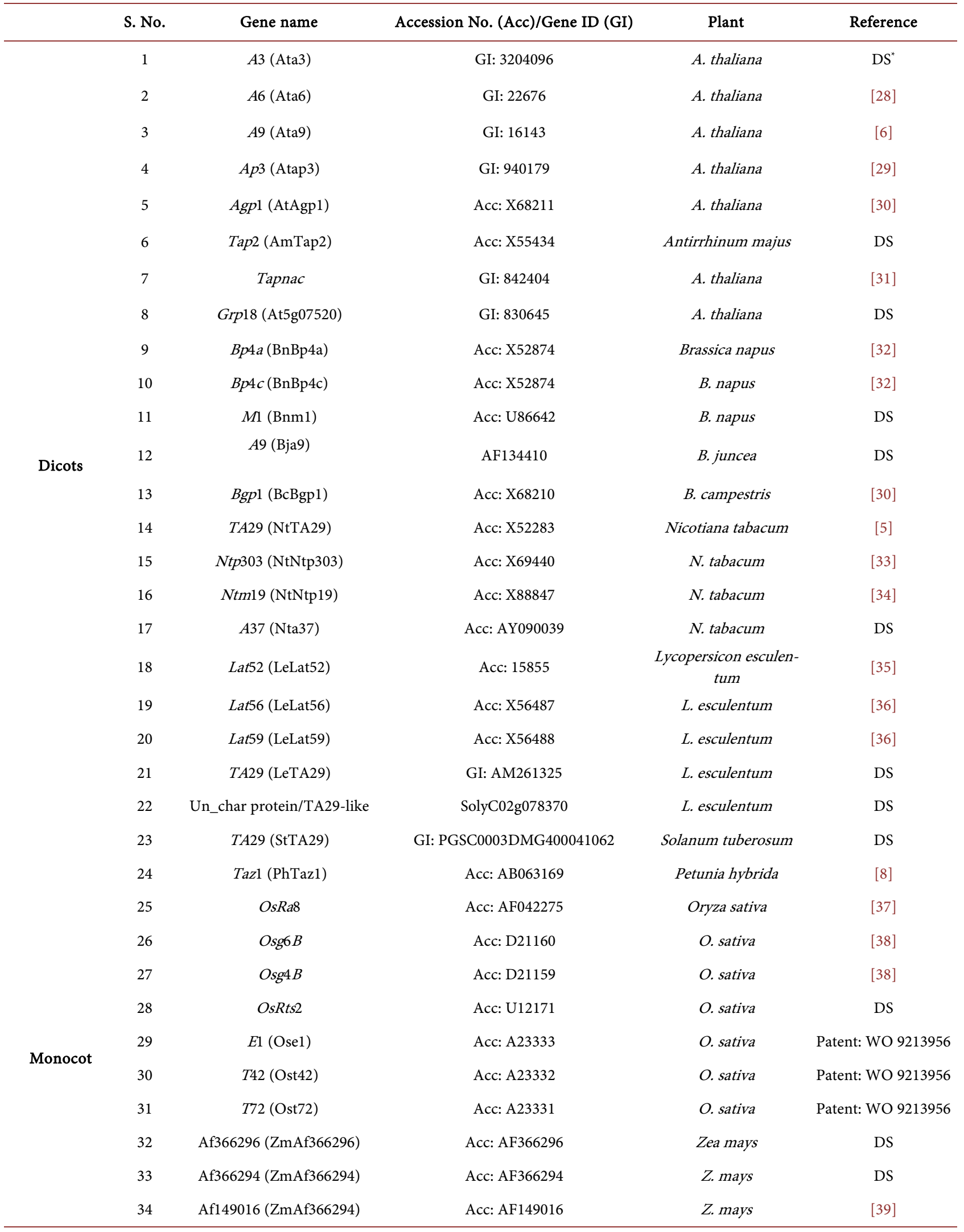

${ }^{*}$ DS-Direct submission. 
The sequences for the respective URMs were downloaded from NCBI website. The sequence files of dicots and monocots URMs thus generated were submitted separately at MEME Tool available online for analysis of conserved motifs. In order to identify the conserved motifs, MEME program was run with different parameters that defined the motif width $(5-13,6-10$ or $6-14)$ and the total number of motifs to be generated was fixed at 10. After identifying the motifs generated using the different widths, it was observed that in most cases, the motif generated with 6 - 14 width encompassed those generated by $5-13$ or $6-10$ width. Thus, the 10 motifs generated with 6 - 14 width were taken for further analysis. The position of the motifs in the different URMs as generated by MEME for both datasets and the sequence of the motifs as identified by MAST are presented in Figure 1 and Figure 2.

After identifying the conserved motifs in the two datasets of anther/tapetum specific genes, the next step was to analyze if these motifs corresponded to any known cis-elements of plant promoters. This was done by creating strings of the identified motifs and submitting it to the PLACE database. This led to the identification of several known cis-elements. This data was then manually curated and 10 known cis-elements were identified that are enlisted in Table 2. It was observed that out of the 10 identified motifs in case of dicots (Figure 1), 6 of them have already been reported in the literature. In this case, no known cis-elements were identified for motifs 1, 2, 8 and 10. In case of monocots, we could identify known cis-elements only for motifs 1,5 and 7 . This could be reflective of the fact that generally more information is available for dicot promoters than those of monocots.

We then attempted to see if there was any information about TFs binding to these cis-elements. In order to do so, we first analyzed the presence of transcription factor binding sites using TFSEARCH tool. TFSEARCH searches highly correlated sequence fragments versus a TFMATRIX that is a transcription factor binding site profile database present in "TRANSFAC" database [27]. Strings of the motifs enlisted in Figure 1 and Figure 2 were submitted as query sequence to TFSEARCH which is available online. These led to the identification of four transcription factors which could bind to these URMs. These were DOF [45] and ICE1 [46] [47] [48] [49] [50] with predicted binding sites present in motif 7 and 5 , respectively for monocot URMs. ICE1 was also found to have binding site in motif 7 of dicot URMs. Further, motif 7 in dicot URM was also a predicted binding site for the TF RAVI [54]. The TF, WRKY710S [55] was observed to have binding sites in URMs of dicots represented by motifs 3, 4 and 5 .

Of the 4 identified TFs, it was observed that only DOF and WRKY710S were found to have binding sites in majority of the URMs analyzed. The other 2 were represented in less than $20 \%$ of the analyzed URMs.

DOF stands for DNA binding with one finger domain proteins. They are a class of zinc finger transcription factors which are present in algae (Chlamydomonas reinhardtii) and moss (Physcomitrella patens) as single gene spreading 
Table 2. Known cis-elements corresponding to identified motifs in Figure 1 and Figure 2 and transcription factors (TFs) binding to it, if any.

\begin{tabular}{|c|c|c|c|c|c|}
\hline S. No. & $\begin{array}{l}\text { Name of } \\
\text { cis-element }\end{array}$ & Putative binding site & Function of the cis-element & TFs & Ref \\
\hline 1 & ARR1AT & $\begin{array}{l}\text { NGATT; } N=\text { A/T/G/C } \\
(\text { Motif } 5 \text { \& } 6 \text { of dicot) }\end{array}$ & $\begin{array}{l}\text { ARR1 is a response regulator; found in Arabidopsis, } \mathrm{N}=\mathrm{G} / \mathrm{A} / \mathrm{C} / \mathrm{T} \text {; } \\
\text { AGATT is also present in the promoter of rice non-symbiotic } \\
\text { haemoglobin-2 (NSHB) gene. }\end{array}$ & None & {$[41][42]$} \\
\hline 2 & BOX-4 & $\begin{array}{c}\text { ATTAAT } \\
\text { (Motif } 9 \text { of dicot) }\end{array}$ & Part of a conserved DNA molecule involved in light responsiveness & None & [43] \\
\hline 3 & CAAT-BOX & $\begin{array}{c}\text { CAAT } \\
\text { (Motif } 7 \text { of dicot) }\end{array}$ & "CAAT promoter consensus sequence" found in $\operatorname{leg} A$ gene of pea & None & [44] \\
\hline 4 & DOFCOREZM & $\begin{array}{c}\text { AAAG } \\
\text { (Motif } 7 \text { of monocot) }\end{array}$ & $\begin{array}{l}\text { Core dof protein binding site was found in maize; zinc finger, and is } \\
\text { unique to plants; Four cDNAs encoding Dof proteins, Dof1, Dof2, } \\
\text { Dof3 and PBF, have been isolated maize; PBF is an endosperm } \\
\text { specific Dof protein that binds to form prolamin box; and enhances } \\
\text { transcription from the promoters of both cytosolic orthophosphate } \\
\text { promoter and non-photosynthetic PEPC gene }\end{array}$ & DOF & [45] \\
\hline 5 & $\begin{array}{l}\text { E-BOXNNAPA/ } \\
\text { MYCCONSENSU } \\
\text { AT }\end{array}$ & $\begin{array}{l}\text { CANNTG; } \mathrm{N}=\mathrm{A} / \mathrm{T} / \mathrm{G} / \mathrm{C} \\
\text { (Motif } 7 \text { of dicot }) \\
\text { (Motif } 5 \text { of monocot) }\end{array}$ & $\begin{array}{l}\text { The site is present in the promoter of } r d 22 \text { (dehydration-responsive } \\
\text { gene) and in many other genes in Arabidopsis, Binding site of } \\
\text { ATMYC2 (previously known as rd22BP1); N = A/T/G/C; MYC } \\
\text { recognition sequence in CBF3 promoter; Binding site of ICE1 } \\
\text { (inducer of CBF expression 1) that regulates the transcription of } \\
\text { CBF/DREB1 genes in the cold in Arabidopsis. E-box of napA } \\
\text { storage-protein gene of Brassica napus. This sequence is also known } \\
\text { as RRE (R response element). }\end{array}$ & ICE1 & $\begin{array}{c}{[46][47]} \\
{[48][49]} \\
{[50]}\end{array}$ \\
\hline 6 & GTGANTG10 & $\begin{array}{c}\text { GTGA } \\
\text { (Motif } 5 \text { of dicot) }\end{array}$ & $\begin{array}{l}\text { "GTGA motif" found in the promoter of the tobacco late pollen gene } \\
\text { g10 which shows homology to pectate lyase and is the putative } \\
\text { homologue of the tomato gene lat } 56 \text {; Located between }-96 \text { and }-93\end{array}$ & None & [51] \\
\hline 7 & $\begin{array}{c}\text { POLLENLELAT5 } \\
2\end{array}$ & $\begin{array}{c}\text { AGAAA } \\
\text { (Motif } 1 \text { of monocot) }\end{array}$ & $\begin{array}{l}\text { Regulatory element responsible for pollen specific activation of } \\
\text { tomato lat } 52 \text { gene; Found at }-72 \text { to }-68 \text { region. Also found in the } \\
\text { promoter of tomato endo-beta-mannanase gene. }\end{array}$ & None & {$[52][53]$} \\
\hline 8 & RAV1AAT & $\begin{array}{c}\text { CAACA } \\
\text { (Motif } 7 \text { of dicot) }\end{array}$ & $\begin{array}{l}\text { RAV1 binding consensus sequence, binds to DNA with bipartite } \\
\text { sequence motifs of RAV1-A (CAACA) and RAV1-B (CACCTG); } \\
\text { RAV1 protein contains AP2-like and B3-like domains which } \\
\text { recognize the CAACA and CACCTG motifs, respectively; The } \\
\text { expression level of RAV1 is relatively high in rosette leaves and roots } \\
\text { in Arabidopsis }\end{array}$ & RAV1 & [54] \\
\hline 9 & WRKY710S & $\begin{array}{c}\text { TGAC } \\
\text { (Motif } 3,4 \& 5 \text { of dicot) }\end{array}$ & $\begin{array}{l}\text { A core of TGAC-containing W-box is present in } A m y 32 b \text { promoter; } \\
\text { is binding site of rice WRKY } 71 \text {, which acts a transcriptional } \\
\text { repressor in the gibberellin signaling pathway; Parsley WRKY } \\
\text { proteins bind specifically to TGAC-containing W box elements } \\
\text { within the Pathogenesis-Related Class10 (PR-10) genes }\end{array}$ & WRKY71 & [55] \\
\hline 10 & 10PEHVPSBD & $\begin{array}{c}\text { TATTC } \\
\text { (Motif } 4 \text { of dicot) }\end{array}$ & $\begin{array}{l}\text { "- } 10 \text { promoter element" present in } p s b D \text { gene promoter of barley; is } \\
\text { required for expression of the } p s b D \text { (plastid gene) encoding } \\
\text { chlorophyll-binding protein of photosystem II reaction center, } \\
\text { activated by blue/UV-A light/white light. }\end{array}$ & None & [56] \\
\hline
\end{tabular}


(a)

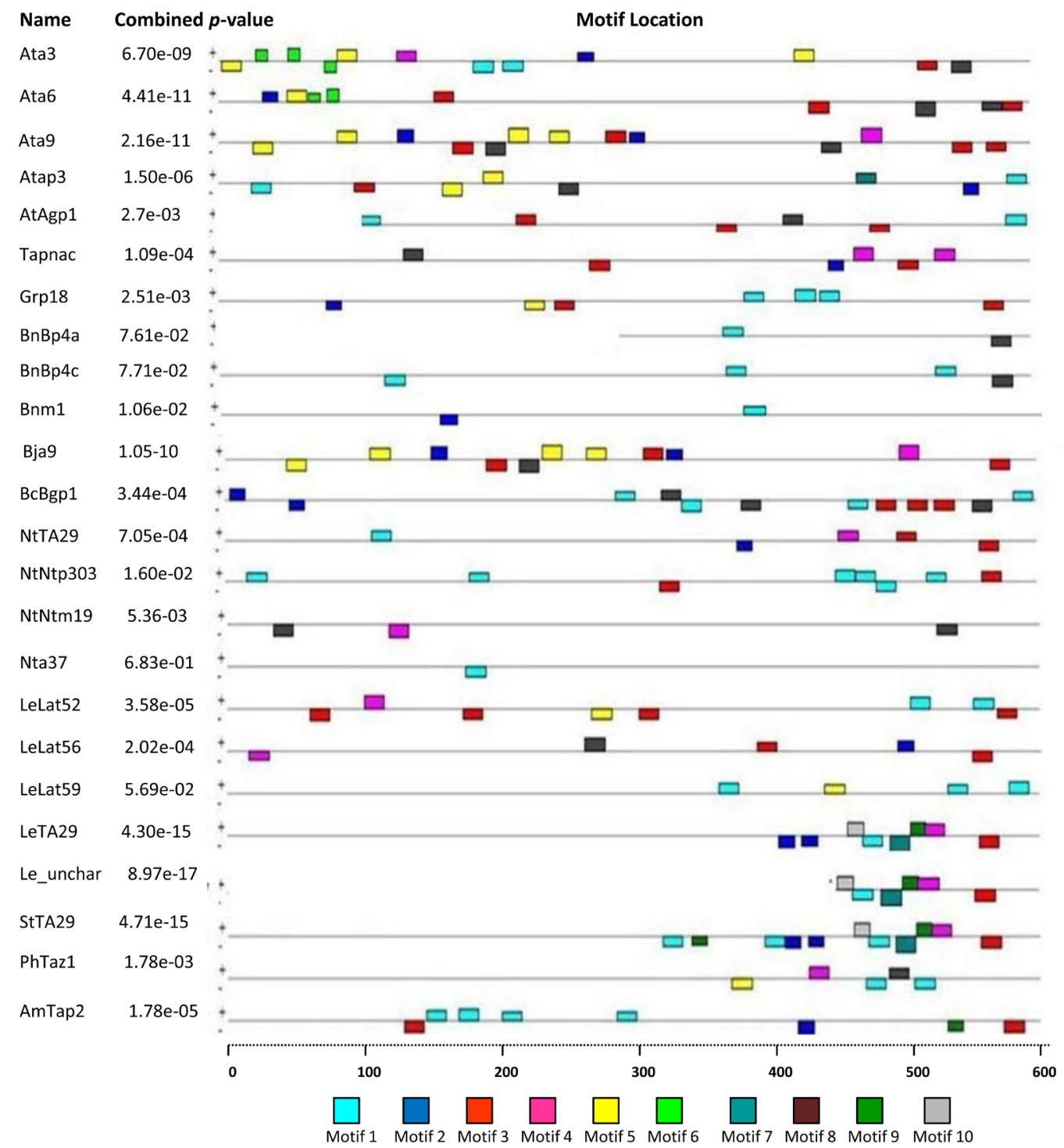

(b)

\begin{tabular}{|c|c|c|c|c|c|}
\hline $\begin{array}{c}\text { Motif } \\
\text { No. }\end{array}$ & Consensus sequence & $\begin{array}{c}\text { \% } \\
\text { representation } \\
\text { in the dataset }\end{array}$ & $\begin{array}{c}\text { Motif } \\
\text { No. }\end{array}$ & Consensus sequence & $\begin{array}{c}\% \\
\text { representation } \\
\text { in the dataset }\end{array}$ \\
\hline \multirow{2}{*}{1} & AAGAAGAAGGAGAA & 75 & $\square_{6}$ & CCGCCGGCG & 8 \\
\hline$\square$ & TGGTGGGAGCG & 58 & $\square_{7}$ & AACACAATTGGAGC & 13 \\
\hline$\square_{3}$ & GTTTTGGTGGGTGA & 71 & $\square_{8}$ & TGGTTTGTTTTGG & 54 \\
\hline$\square_{4}$ & CCTATTTATTCTC & 50 & $\square_{9}$ & GGAACTTGTGG & 17 \\
\hline$\square$ & GGTCACCCTCGAA & 38 & $\square_{10}$ & GTGCCTCAGA & 13 \\
\hline
\end{tabular}

Figure 1. Analysis of conserved motifs in URM (600 bp) of anther/tapetum specific genes of dicots using MEME tool. (a) Placement of the motifs in the URMs and (b) the consensus sequence of the various motifs obtained from MAST analysis. The presence of each motif in different promoters is mentioned as \% representation. 
(a)

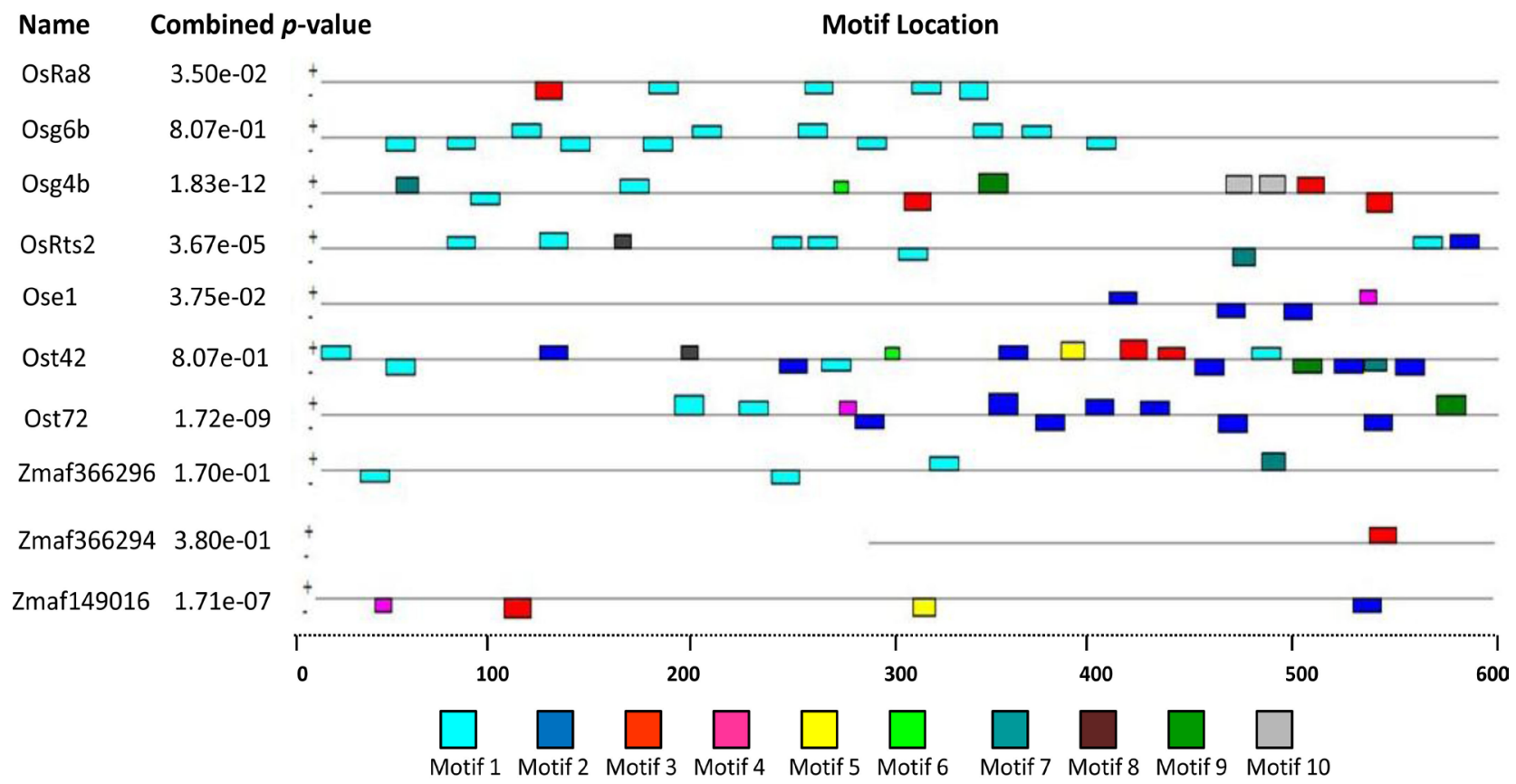

(b)

\begin{tabular}{|c|c|c|c|c|c|}
\hline $\begin{array}{c}\text { Motif } \\
\text { No. }\end{array}$ & Consensus sequence & $\begin{array}{c}\% \\
\text { representation } \\
\text { in the dataset }\end{array}$ & $\begin{array}{c}\text { Motif } \\
\text { No. }\end{array}$ & Consensus sequence & $\begin{array}{c}\% \% \\
\text { representation } \\
\text { in the dataset }\end{array}$ \\
\hline 1 & AAAAAAAAAGAAA & 70 & 6 & CGGGGCC & 20 \\
\hline 2 & GGCGCGCGCGCGGTG & 50 & 7 & GTTGGGGGGTC & 40 \\
\hline 3 & GCCGCTGCTGCTT & 50 & 8 & CCACGCCC & 20 \\
\hline 4 & CGCCGGCC & 30 & 9 & GAGCCCCACGGCGG & 30 \\
\hline 5 & CCCACGTGCCG & 20 & 10 & CCGGCCGCCCCC & 10 \\
\hline
\end{tabular}

Figure 2. Analysis of conserved motifs in URM (600 bp) of anther/tapetum specific genes of monocots using MEME tool. (a) Placement of the motifs in the URMs and (b) the consensus sequence of the various motifs obtained from MAST analysis. The presence of each motif in different promoters is mentioned as \% representation.

across lower and higher plants possessing multiple genes encoding the Dof domain containing protein [57]. Its cDNA was first isolated from maize [58] and in higher plants the Dof domain containing proteins have been identified in Arabidopsis, tomato, potato, pumpkin, pea, wheat, rice and barley [59]. The Dof domain is involved in both protein-protein interaction and acts as a DNA binding domain. The sequence specific binding of the Dof domain to AAAG motif has been verified by both in vivo and in vitro experiments [60] [61]. The Dof domain proteins are known to be involved in biological processes like seed germination, development and plant defense and light responses where they act as 
both activator and repressors [59] [62]. It is involved in regulation of genes of specific pathway for carbon metabolism in maize where it regulates C4PEPC (C4 photosynthetic phosphoenol-pyruvate carboxlase), cyPPDK (cytosolic pyruvate orthophosphate dikinase) and non photosynthetic PEPC [45].

WRKY71 belongs to WRKY family of transcription factors. They are reported to be present across lower eukaryotes (protista) to ferns (pteridophytes) and in plants [63]. The WRKY family members are identified by the presence of a conserved 60 amino acid residue region and a zinc finger domain. Promoters of genes carrying the $\mathrm{W}$-box are potential targets of the WRKY factors [55]. They are key components in the innate immunity of the plant and bind to the W-box of pathogenesis related genes [55] [64]. They are involved in seed and trichome development and embryogenesis [63]. They function as both activators and repressors by protein-protein interaction and autoregulation [65]. WRKY71 expresses in the aleurone layer in rice and is reported to function as a repressor of gibberellic acid signalling pathway in aleurone layer cells. GA pathway is involved in growth and development of plants [66].

The present analysis has led to the identification of certain elements and TFs that could regulate tapetum specific promoters. However, the role of these needs to be experimentally analysed. This can be done by a "loss-of-function" strategy in which the cis-elements in a given URM are mutated and changes in promoter activity, if any are analysed. In a second strategy, "gain-of function", a given TF can be ectopically expressed and its influence on the activity of a given URM is recorded.

\section{Acknowledgements}

This work was supported by a grant from University of Delhi, New Delhi. PAS was supported by a research fellowship from Council of Scientific and Industrial Research (CSIR), New Delhi, India.

\section{References}

[1] Koltunow, A.M., Truettner, J., Cox, K.H., Wallroth, M. and Goldberg, R.B. (1990) Different Temporal and Spatial Gene Expression Patterns Occur during Anther Development. The Plant Cell, 2, 1201-1224. https://doi.org/10.1105/tpc.2.12.1201

[2] Goldberg, R.B., Beals, T.P. and Sanders, P.M. (1993) Anther Development: Basic Principles and Practical Applications. The Plant Cell, 5, 1217-1229. https://doi.org/10.1105/tpc.5.10.1217

[3] Polowick, P.L. and Sawhney, V.K. (1993) Differentiation of the Tapetum during Microsporogenesis in Tomato (Lycopersicon esculentum Mill.), with Special Reference to the Tapetal Cell Wall. Annals of Botany, 72, 595-605. https://doi.org/10.1006/anbo.1993.1150

[4] Furness, C.A. and Rudall, P.J. (2001) Pollen and Anther Characters in Monocot Systematics. Grana, 40, 17-25. https://doi.org/10.1080/00173130152591840

[5] Mariani, C., De Beuckeleer, M., Truettner, J., Leemans, J. and Goldberg, R.B. (1990) Induction of Male Sterility in Plants by a Chimaeric Ribonuclease Gene. Nature, 347, 737-741. https://doi.org/10.1038/347737a0 
[6] Paul, W., Hodge, R., Smartt, S., Draper, J. and Scott, R. (1992) The Isolation and Characterisation of the Tapetum-Specific Arabidopsis. Plant Molecular Biology, 19, 611-622. https://doi.org/10.1007/BF00026787

[7] Asano, T., Masumura, T., Kusano, H., Kikuchi, S., Kurita, A. and Shimada, H. (2002) Construction of a Specialized cDNA Library from Plant Cells Isolated by Laser Capture Microdissection: Toward Comprehensive Analysis of the Genes Expressed in the Rice Phloem. Plant Journal, 32, 401-408.

https://doi.org/10.1046/j.1365-313X.2002.01423.x

[8] Kapoor, S., Kobayashi, A. and Takatsuji, H. (2002) Silencing of the Tapetum-Specific Zinc Finger Gene TAZ1 Causes Premature Degeneration of Tapetum and Pollen Abortion in Petunia. The Plant Cell Online, 14, 2353-2367.

https://doi.org/10.1105/tpc.003061

[9] Kerk, N.M., Ceserani, T., Tausta, S.L., Sussex, I.M. and Nelson, T.M (2003) Laser Capture Microdissection of Cells from Plant Tissues. Plant Physiology, 132, 27-35. https://doi.org/10.1104/pp.102.018127

[10] Nakazono, M., Qui, F., Brsuk, L.A. and Schnable, P.S. (2003) Laser Capture Microdissection, a Tool for the Global Analysis of Gene Expression in Specific Plant Cell Type: Identification of Genes Expressed Differentially in Epidermal Cell or Vascular Tissues of Maize. Plant Cell, 15, 583-596. https://doi.org/10.1105/tpc.008102

[11] Day, R.C., Grossniklaus, U. and Macknight, R.C. (2005) Be More Specific Laser-Assisted Microdissection of Plant Cells. Trends in Plant Science, 10, 397-406. https://doi.org/10.1016/j.tplants.2005.06.006

[12] Nelson, T., Tausta, S.L., Gandotra, N. and Liu, T. (2006) Laser Microdissection of Plant Tissue: What You See Is What You Get. Annual Review of Plant Biology, 57, 181-201. https://doi.org/10.1146/annurev.arplant.56.032604.144138

[13] Ohtsu, K., Takahashi, H., Schnable, P.S. and Nakazono, M. (2007) Cell Type-Specifi c Gene Expression Profi Ling in Plants by using a Combination of Laser Microdissection and High-Throughput Technologies. Plant Cell Physiology, 48, 3-7. https://doi.org/10.1093/pcp/pcl049

[14] Hobo, T., Suwabe, K., Aya, K., Suzuki, G., Yano, K., Ishimizu, T., Fujita, M., Kikuchi, S., Hamada, K., Miyano, M., Fujioka, T., Kaneko, F., Kazama, T., Mizuta, Y., Takahashi, H., Shiono, K., Nakazono, M., Tsutsumi, N., Nagamura, Y., Kurata, N., Watanabe, M. and Matsuoka, M. (2008) Various Spatiotemporal Expression Profiles of Anther-Expressed Genes in Rice. Plant and Cell Physiology, 49, 1417-1428. https://doi.org/10.1093/pcp/pcn128

[15] Kuriakose, B, Arun, V., Gnanamanickam, S.S. and Thomas, G. (2009) Tissue-Specific Expression in Transgenic Rice and Arabidopsis thaliana Plants of GUS Gene Driven by the 50 Regulatory Sequences of an Anther Specific Rice Gene YY2. Plant Science, 177, 390-397. https://doi.org/10.1016/j.plantsci.2009.06.016

[16] Le, B.H., Cheng, C., Bui, A.Q., Wagmaister, J.A., Henry, K.F., Pelletier, J., Kwong, L., Belmonte, M., Kirkbride, R., Horvath, S., Drews, G.N., Fischer, R.L., Okamuro, J.K., Harada, J.J. and Goldberg, R.B. (2010) Global Analysis of Gene Activity during Arabidopsis Seed Development and Identification of Seed-Specific Transcription Factors. PNAS, 107, 8063-8070. https://doi.org/10.1073/pnas.1003530107

[17] Jagannath, A., Bandyopadhyay, P., Arumugam, N., Gupta, V., Burma, P.K. and Pental, D. (2001) The Use of a Spacer DNA Fragment Insulates the Tissue-Specific Expression of a Cytotoxic Gene (barnase) and Allows High-Frequency Generation of Transgenic Male Sterile Lines in Brassica juncea L. Molecular Breeding, 8, 11-23. https://doi.org/10.1023/A:1011916216191 
[18] Jagannath, A., Arumugam, N., Gupta, V., Pradhan, A., Burma, P.K. and Pental, D. (2002) Development of Transgenic Barstar Lines and Identification of a Male Sterile (Barnase)/Restorer (Barstar) Combination for Heterosis Breeding in Indian Oilseed Mustard (Brassica juncea). Current Science, 82, 46-52.

[19] Bisht, N.C., Jagannath, A., Gupta, V., Burma, P.K. and Pental, D. (2004) A Two Gene-Two Promoter System for Enhanced Expression of a Restorer Gene (Barstar) and Development of Improved Fertility Restorer Lines for Hybrid Seed Production in Crop Plants. Molecular Breeding, 14, 129-144. https://doi.org/10.1023/B:MOLB.0000038002.45312.08

[20] Ray, K., Bisht, N.C., Pental, D. and Burma, P.K. (2007) Development of Transgenic barnase/Barstartransgenics for Hybrid Seed Production in Indian Oilseed Mustard (Brassica juncea 1 Czern\&Coss) using a Mutant Acetolactate Synthase Gene Conferring Resistance to Imidazole-Based Herbicide "Pursuit". Current Science, 93, 1390-1396.

[21] Kempe, K. and Gils, M. (2011) Pollination Control Technologies for Hybrid Breeding. Molecular Breeding, 27, 417-437. https://doi.org/10.1007/s11032-011-9555-0

[22] Liu, X., Shangguan, Y., Zhu, J., Lu, Y. and Han, B. (2013) The Rice OsLTP6 Gene Promoter Directs Anther-Specific Expression by a Combination of Positive and Negative Regulatory Elements. Planta, 238, 845-857. https://doi.org/10.1007/s00425-013-1934-9

[23] Verma, N. and Burma, P. (2014) A Method to Synthesize cDNA Constructs by Homology Based Recombination Cloning. American Journal of Molecular Biology, 4, 16-19. https://doi.org/10.4236/ajmb.2014.41003

[24] Bailey, T.L., Boden, M., Buske, F.A., Frith, M., Grant, C.E., Clementi, L. and Noble, W.S. (2009) MEME Suite: Tools for Motif Discovery and Searching. Nucleic Acids Research, 2, 202-208. https://doi.org/10.1093/nar/gkp335

[25] Higo, K., Ugawa, Y., Iwamoto, M. and Korenaga, T. (1999) Plant Cis-Acting Regulatory DNA Elements (PLACE) Database. Nucleic Acids Research, 27, 297-300. https://doi.org/10.1093/nar/27.1.297

[26] Bailey, T.L. and Gribskov, M. (1998) Combining Evidence using p-Values: Application to Sequence Homology Searches. Bioinformatics, 14, 48-54. https://doi.org/10.1093/bioinformatics/14.1.48

[27] Heinemeyer, T., Wingender, R.E., Hermjakob, I.H., Kel, A.E. and Kel, O.V. (1998) Databases on Transcriptional Regulation: Transfac, Trrd and Compel. Nucleic Acids Research, 26, 362-367. https://doi.org/10.1093/nar/26.1.362

[28] Hird, D.L., Worrall, D., Hodge, R., Smartt, S., Paul, W. and Scott, R. (1993) The Anther-Specific Protein Encoded by the Brassica napus and Arabidopsis thaliana A6 Gene Displays Similarity to Beta-1,3-Glucanases. The Plant Journal: For Cell and Molecular Biology, 4, 1023-1033. https://doi.org/10.1046/j.1365-313X.1993.04061023.x

[29] Irish, V.F. And Yamamoto, Y.T. (1995) Conservation of Floral Homeotic Gene Function between Arabidopsis and Antirrhinum. The Plant Cell, 7, 1635-1644. https://doi.org/10.1105/tpc.7.10.1635

[30] Xu, H., Davies, S.P., Kwan, B.Y., O’Brien, A.P., Singh, M. and Knox, R.B. (1993) Haploid and Diploid Expression of a Brassica campestris Anther-Specific Gene Promoter in Arabidopsis and Tobacco. Molecular \& General Genetics, 239, 58-65.

[31] Alvarado, V.Y., Tag, A. and Thomas, T.L. (2011) A cis Regulatory Element in the TAPNAC Promoter Directs Tapetal Gene Expression. Plant Molecular Biology, 75, 129-139. https://doi.org/10.1007/s11103-010-9713-5 
[32] Albani, D., Robert, L.S., Donaldson, P.A., Altosaar, I., Arnison, P.G. and Fabijanski, S.F. (1990) Characterization of a Pollen-Specific Gene Family from Brassica napus Which Is Activated during Early Microspore Development. Plant Molecular Biology, 15, 605-622. https://doi.org/10.1007/BF00017835

[33] Weterings, K., Reijnen, W., Wijn, G., Heuvel, K.V.D., Appeldoorn, N., Kort, G.D., Herpen, M.V., Schrauwen, J. and Wullems, G. (1995) Molecular Characterization of the Pollen-Specific Genome Clone Ntpg303 and in Situ Localization of Expression. Sexual Plant Reproduction, 8, 11-17. https://doi.org/10.1007/BF00228757

[34] Oldenhof, M.T., de Groot, P.F., Visser, J.H., Schrauwen, J.A. and Wullems, G.J. (1996) Isolation and Characterization of a Microspore-Specific Gene from Tobacco. Plant Molecular Biology, 31, 213-225. https://doi.org/10.1007/BF00021785

[35] Twell, D., Wing, R.A., Yamaguchi, J. and McCormick, S. (1993) Isolation and Expression of an Anther Specific Gene from Tomato. Molecular and General Genetics, 217, 240-245. https://doi.org/10.1007/BF02464887

[36] Twell, D., Yamaguchi, J., Wing, R.A., Ushiba, J. and McCormick, S. (1991) Promoter Analysis of Genes That Are Coordinately Expressed during Pollen Development Reveals Pollen-Specific Enhancer Sequences and Shared Regulatory Elements. Genes and Development, 5, 496-507. https://doi.org/10.1101/gad.5.3.496

[37] Jeon, J., Chung, Y., Lee, S., Yi, G., Oh, B. and An, G. (1999) Isolation and Characterization of an Anther-Specific Gene RA8, from Rice (Oryza sativa L.). Plant Molecular Biology, 39, 35-44. https://doi.org/10.1023/A:1006157603096

[38] Tsuchiya, T., Toriyama, K., Ejiri, S.I. and Hinata, K. (1994) Molecular Characterization of Rice Genes Specifically Expressed in the Anther Tapetum. Plant Molecular Biology, 26, 1737-1746. https://doi.org/10.1007/BF00019488

[39] Bih, F.Y., Wu, S.H., Ratnayake, C., Walling, L.L., Nothnagel, E.A. and Huang, A.H.C. (1999) The Predominant Protein on the Surface of Maize Pollen Is an Endoxylanase Synthesized by a Tapeturn mRNA with a Long 5' Leader. Journal of Biological Chemistry, 274, 22884-22894. https://doi.org/10.1074/jbc.274.32.22884

[40] Kanoria, S. and Burma, P.K. (2012) A 28 nt Long Synthetic 5'UTR (synJ) as an Enhancer of Transgene Expression in Dicotyledonous Plants. BMC Biotechnology, 12, 85. https://doi.org/10.1186/1472-6750-12-85

[41] Ross, E.J.H., Stone, J.M., Elowsky, C.G., Arredondo-Peter, P., Klucas, R.V. and Sarath, G. (2004) Activation of the Oryza sativa Non-Symbiotic Haemoglobin-2 Promoter by the Cytokinin-Regulated Transcription Factor, ARR1. Journal of EXperimental Botany, 55, 1721-1731. https://doi.org/10.1093/jxb/erh211

[42] Sakai, H., Aoyama, T. and Oka, A. (2004) Arabidopsis ARR1 and ARR2 Response Regulators Operate as Transcriptional Activators. Plant Journal, 24, 703-711.

[43] Lois, R., Dietrich, A., Hahlbrock, K. and Schulz, W. (1989) A Phenylalanine Ammonia-Lyase Gene from Parsley: Structure, Regulation and Identification of Elicitor and Light Responsive Cis-Acting Elements. EMBO Journal, 8, 1641-1648.

[44] Shirsat, A., Wilford, N., Croy, R. and Boulter, D. (1989) Sequences Responsible for the Tissue Specific Promoter Activity of a Pea Legumin Gene in Tobacco. Molecular Genes and Genetics, 215, 326-331. https://doi.org/10.1007/BF00339737

[45] Yanagisawa, S. (2000) Dof1 and Dof2 Transcription Factors Are Associated with Expression of Multiple Genes Involved in Carbon Metabolism in Maize. The Plant Journal, 21, 281-288. https://doi.org/10.1046/j.1365-313x.2000.00685.x

[46] Chinnusamy, V., Ohta, M., Kanrar, S., Lee, B.H., Hong, X., Agarwal, M. and Zhu, J.K. (2003) ICE1: A Regulator of Cold-Induced Transcriptome and Freezing Toler- 
ance in Arabidopsis. Genes and Development, 17, 1043-1054.

https://doi.org/10.1101/gad.1077503

[47] Abe, H., Urao, T.I.T., Seki, M., Shinozaki, K. and Yamaguchi-Shinozaki, K. (2003) Arabidopsis AtMYC2 (bHLH) and AtMYB2 (MYB) Function as Transcriptional Activators in Abscisic Acid Signaling. The Plant Cell, 15, 63-78. https://doi.org/10.1105/tpc.006130

[48] Hartmann, U., Sagasser, M., Mehrtens, F., Stracke, R. and Weisshaar, B. (2005) Differential Combinatorial Interactions of Cis-Acting Elements Recognized by R2R3-MYB, BZIP, and BHLH Factors Control Light-Responsive and Tissue-Specific Activation of Phenylpropanoid Biosynthesis Genes. Plant Molecular Biology, 57, 155-171. https://doi.org/10.1007/s11103-004-6910-0

[49] Agarwal, P.K., Agarwal, P., Reddy, M.K. and Sopory, S.K. (2006) Role of DREB Transcription Factors in Abiotic and Biotic Stress Tolerance in Plants. Plant Cell Reports, 25, 1263-1274. https://doi.org/10.1007/s00299-006-0204-8

[50] Stalberg, K., EllerstroÈm, M., Ezcurra, I., Ablov, S. and Rask, L. (1996) Disruption of an Overlapping E box=ABRE Motif Abolished High Transcription of the napA Storage Protein Promoter in Transgenic Brassica napus Seeds. Planta, 199, 515-524. https://doi.org/10.1007/BF00195181

[51] Rogers, H.J., Bate, N., Combe, J., Sullivan, J., Sweetman, J., Swan, C. and Twell, D. (2001) Functional Analysis of Cis-Regulatory Elements within the Promoter of the Tobacco Late Pollen Gene g10. Plant Molecular Biology, 45, 577-585. https://doi.org/10.1023/A:1010695226241

[52] Bate, N. and Twell, D. (1998) Functional Architecture of a Late Pollen Promoter: Pollen-Specific Transcription Is Developmentally Regulated by Multiple Stage-Specific and Co-Dependent Activator Elements. Plant Molecular Biology, 37, 859-869. https://doi.org/10.1023/A:1006095023050

[53] Filichkin, S.A., Leonard, J.M., Monteros, A., Liu, P.P. and Nonogaki, H. (2004) A Novel Endo-Beta-Mannanase Gene in Tomato LeMAN5 Is Associated with Anther and Pollen Development. Plant Physiology, 134, 1080-1087. https://doi.org/10.1104/pp.103.035998

[54] Kagaya, Y., Ohmiya, K. and Hattori, T. (1999) RAV1, a Novel DNA-Binding Protein, Binds to Bipartite Recognition Sequence through Two Distinct DNA-Binding Domains Uniquely Found in Higher Plants. Nucleic Acids Research, 27, 470-478. https://doi.org/10.1093/nar/27.2.470

[55] Eulgem, T., Rushton, P.J., Robatzek, S. and Somssich, I.E. (2000) The WRKY Super Family of Plant Transcription Factors. Trends in Plant Science, 1360-1385.

[56] Thum, K.E., Kim, M., Morishige, D.T., Eibl, C., Koop, H.U. and Mullet, J.E. (2001) Analysis of Barley Chloroplast psbD Responsive Promoter Elements in Tranplastomic Tobacco. Plant Molecular Biology, 3, 353-366.

https://doi.org/10.1023/A:1011616400264

[57] Noguero, M., Atif, M.R., Sergio, O. and Thompson, R.D. (2013) The Role of the DNA-Binding One Zinc Finger (DOF) Transcription Factor Family in Plants. Plant Science, 209, 32-45. https://doi.org/10.1016/j.plantsci.2013.03.016

[58] Yanagisawa, S. and Izui, K. (1993) Molecular Cloning of Two DNA-Binding Proteins of Maize That Are Structurally Different But Interact with the Same Sequence Motif. Journal of Biological Chemistry, 268, 16028-16036.

[59] Yanagisawa, S. (2004) Dof Domain Proteins: Plant-Specific Transcription Factors Associated with Diverse Phenomena Unique to Plants. Plant Cell and Physiology, 45, 386-391. https://doi.org/10.1093/pcp/pch055 
[60] Yanagisawa, S. and Schmidt, R.J. (1999) Diversity and Similarity among Recognition Sequences of Dof Transcription Factors. Plant Journal, 17, 209-214. https://doi.org/10.1046/j.1365-313X.1999.00363.x

[61] Yanagisawa, S. and Sheen, J. (1998) Involvement of Maize Dof Zinc Finger Proteins in Tissue-Specific and Light-Regulated Gene Expression. Plant Cell, 10, 75-89. https://doi.org/10.1105/tpc.10.1.75

[62] Yanagisawa, S. (2002) The Dof Family of Plant Transcription Factors. Trends in Plant Science, 7, 555-560. https://doi.org/10.1016/S1360-1385(02)02362-2

[63] Agarwal, P., Reddy, M.P. and Chikara, J. (2011) WRKY: Its Structure, Evolutionary Relationship, DNA-Binding Selectivity, Role in Stress Tolerance and Development of Plants. Molecular Biology Reports, 38, 3883-3896. https://doi.org/10.1007/s11033-010-0504-5

[64] Paul, J., Rushton, P.J., Somssich, I.E., Ringler, P. and Shen, Q.J. (2012) WRKY Transcription Factors. Trends in Plant Science, 15, 247-258. https://doi.org/10.1016/j.tplants.2010.02.006

[65] Chen, L., Song, Y., Li, S., Zhang, L., Zou, C. and Yu, D. (2012) The Role of WRKY Transcription Factors in Plant Abiotic Stresses. Biochimica et Biophysica Acta Gene Regulatory Mechanisms, 1819, 120-128. https://doi.org/10.1016/j.bbagrm.2011.09.002

[66] Zhang, Z., Xie, Z., Zou, X., Casaretto, J., Ho, T.D. and Shen, Q.J. (2004) A Rice WRKY Gene Encodes a Transcriptional Repressor of the Gibberellin Signaling Pathway in Aleurone Cells. Plant Physiology, 134, 1500-1513.

https://doi.org/10.1104/pp.103.034967 